\title{
Synthesis of Orthogonally Protected Muramic Acid Building Blocks for Solid Phase Peptide Synthesis
}

\author{
Kristina Vlahoviček-Kahlina and Andreja Jakas* \\ Division of Organic Chemistry and Biochemistry, Ruđer Bošković Institute, Bijenička c. 54, 10000 Zagreb, Croatia
}

RECEIVED JANUARY 29, 2015; REVISED MARCH 23, 2015; ACCEPTED APRIL 15, 2015

\begin{abstract}
Muramic acid is found in many peptide natural products containing oligo(poly)saccharide moieties. Taking into consideration that the Fmoc methodology is routinely used for solid-phase peptide synthesis, preparation of orthogonally protected muramic acid building blocks for total solid-phase synthesis of these natural products is of particular practical importance. Herein a simple and efficient synthesis of benzyl 2-amino-4,6-O-benzylidene-3-O-[(R)-1-carboxyethyl]-2-deoxy- $N$-9-fluorenylmethyloxycarbonyl$\alpha$-D-glucopyranoside (6) from $N$-acetylglucosamine (1) is described. Important improvements over previous synthetic approaches to glucopyranosides 2 (benzyl 2-acetamido-2-deoxy- $\alpha$-D-glucopyranoside) and $\mathbf{3}$ (benzyl 2-acetamido-4,6-O-benzylidene-2-deoxy- $\alpha$-D-glucopyranoside), key building blocks in preparation of 6, include synthesis simplification and efficient isolation and purification. Optically pure $(S)-2$ chloropropionic acid 7 was prepared and introduced to the positon 3-O of sugar moiety to give compound 4 (benzyl 2-acetamido-4,6-O-benzylidene-3-O-[(R)-1-carboxyethyl]-2-deoxy- $\alpha$-D-glucopyranoside) with the $(R)$-configuration of the lactyl side-chain in excellent overall yield and optical purity. Deacetylation of amino group gave compound 5 (benzyl 2-amino-4,6- $O$-benzylidene-3- $O-[(R)-1$-carboxyethyl]-2-deoxy- $\alpha$ D-glucopyranoside) suitable for incorporation of the Fmoc protecting group to give protected muramic acid derivative 6 , a useful building block in peptide synthesis.
\end{abstract}

Keywords: dipeptide isostere, muramic acid, solid phase peptide synthesis (SPPS), sugar amino acid (SAA)

\section{INTRODUCTION}

Sugar amino acids (SAAs) are defined as carbohydrate-based compounds that feature an amine and a carboxylate. ${ }^{1-7}$ As such, SAAs are widely spread in nature, and neuraminic acid and $N$-acetylmuramic acid constitute important structural elements in many oligo(poly)saccharides and glycoconjugates. ${ }^{1}$ Muramic acid has been shown to be the main component of the peptidoglycan chain, which constitutes a building unit of the bacterial cell walls and spores. ${ }^{8}$ The discovery that the minimal adjuvant active structure of bacterial peptidoglycans is the muramyl dipeptide $N$-acetylmuramyl-L-alanyl-D-isoglutamine (MDP) has generated a great deal of interest in muramic acid derivatives preparation. ${ }^{9}, 10$ The potential utilisation of a simple and well-defined synthetic adjuvant molecule as MDP, showing maximal stimulation of the immune response but little toxicity and other side effects, has heralded a new era in immunology especially in the field of new vaccine development. ${ }^{11}$ Interestingly, SAAs in nature are almost exclusively linked through interglycosidic bonds, not through amide bonds. The relevance of the hybrid nature of SAAs is evident by the multitude of reported applications in which selected amino acid residues are replaced by SAA in biologically relevant oligopeptides. Thus the outcome of this replacement can be twofold: 1) The nature of the parent carbohydrate (the furan or pyran ring) in combination with the positioning of the amine and carboxylate may affect a desired secondary structure on the target oligopeptide, 2) the residual functionalities on the furan/pyran core may be used to introduce additional desirable properties to the peptide. ${ }^{12}$ Despite the growing interest for the use of SAAs in preparation of unusual peptides with unique structural and biological properties, there is no reported strategy that describes efficient synthesis of orthogonally protected SAA suitable for the Fmoc-solid phase peptide synthesis. ${ }^{13-18}$ Herein we describe the synthesis of optically pure orthogonally protected muramic acid were the impurities of the isomuramic acid were avoided by using optically pure (S)-2-chloropropionic acid for introduction of lactyl group to sugar moiety.

\footnotetext{
* Author to whom correspondence should be addressed. (E-mail: andreja.jakas@irb.hr)
} 


\section{EXPERIMENTAL}

Melting points were determined on a Tottoli (Büchi) apparatus and are uncorrected. Optical rotations were measured at $25^{\circ} \mathrm{C}$ using an Optical Activity LTD automatic AA-10 polarimeter. NMR spectra were recorded on a Bruker AV 600 spectrometer, operating at 150.91 $\mathrm{MHz}$ for ${ }^{13} \mathrm{C}$ and $600.13 \mathrm{MHZ}$ for ${ }^{1} \mathrm{H}$ nuclei. The spectra were measured in DMSO- $d_{6}$ and $\mathrm{CDCl}_{3}$ solutions at $25^{\circ} \mathrm{C}$. Chemical shifts in parts per million were referenced to tetrametylsilane (TMS) and expressed in ppm. Spectra were assigned based one dimensional ${ }^{1} \mathrm{H},{ }^{13} \mathrm{C}$ and APT (Attached Proton Test) and 2D homonuclear COSY (Correlation Spectroscopy) and heteronuclear HMQC (Heteronuclear Multiple-Quantum Correlation) and HMBC (Heteronuclear Multiple Bond Correlation) experiments. Mass spectra were recorded on a triple quadrupole Agilent 6410 spectrometer operating in Electrospray ionization (ESI) mode. Analytical TLC was carried out on silica gel 60 with detection by charring with $10 \% \mathrm{H}_{2} \mathrm{SO}_{4}$. Column chromatography was performed on silica gel (Merck, 0.040-0.063 mm). Following solvent systems were used: A) EtOAc: EtOH: HOAc: $\mathrm{H}_{2} \mathrm{O}=70: 10: 2: 2 v / v / v / v$; B) EtOAc: HOAc: $\mathrm{H}_{2} \mathrm{O}=70: 2: 2 v / v / v$; C) $\left.\mathrm{CH}_{2} \mathrm{Cl}_{2}: \mathrm{MeOH}=9: 1 v / v ; \mathrm{D}\right)$ EtOAc: $\mathrm{HOAc}: \mathrm{H}_{2} \mathrm{O}=70: 1: 1 v / v / v$; E) EtOAc: $\mathrm{EtOH}$ : HOAc: $\mathrm{H}_{2} \mathrm{O}=70: 20: 2: 2 v / v / v / v$. $N$-acetylglucosamine (1), benzyl alcohol, $p$-toluene sulfonic acid monohydrate, benzaldehyde, Fmoc-OSu, $\mathrm{NaH}$ and $\mathrm{ZnCl}_{2}$ were purchased from Sigma-Aldrich.

Benzyl 2-acetamido-2-deoxy- $\alpha$-D-glucopyranoside (2) ${ }^{19}$ $N$-acetylglucosamine (1) $(10 \mathrm{~g}, 0.045 \mathrm{~mol})$ and benzyl alcohol $(72 \mathrm{~mL})$ were suspended in toluene $(120 \mathrm{~mL})$ and $p$-toluene sulfonic acid monohydrate $(500 \mathrm{mg})$ was added. The reaction mixture was refluxed $\left(130^{\circ} \mathrm{C}\right)$ in a Dean-Stark apparatus with water removal by azeotropic mixture. After $4 \mathrm{~h}$, the reaction mixture was cooled to ambient temperature and saturated solution of sodium hydrogen carbonate was added to $\mathrm{pH} \sim 6$. Toluene was removed under reduced pressure. Residue was split into ether-hexane (vol. ratio $=2: 1,260 \mathrm{~mL}$ ) mixture. Reaction mixture was vigorously stirred for $3 \mathrm{~h}$ and left overnight in refrigerator. The amorphous precipitate was filtered off, washed with ether and the crude product recrystallized from 2-propanol to yield colourless crystals $2(10.1 \mathrm{~g}, 72 \%$ yield $) . R_{\mathrm{f}}(\mathrm{A})=0.42 ;$ m.p. $186-187^{\circ} \mathrm{C}$ (lit. $\left.185-186^{\circ} \mathrm{C}\right)^{20} ;[\alpha]_{\mathrm{D}}=+170^{\circ} c 1$, water (lit. $[\alpha]_{\mathrm{D}}=$ $+168^{\circ} c 1$, water) ${ }^{20} ;{ }^{1} \mathrm{H}$ NMR (DMSO- $\left.d_{6}\right) \delta /$ ppm: 7.81 (d, $1 \mathrm{H}, J=8.2 \mathrm{~Hz}, \mathrm{NH}), 7.35-7.28(\mathrm{~m}, 5 \mathrm{H}, \mathrm{Ph}), 5.01(\mathrm{~d}$, $1 \mathrm{H}, J=5.8 \mathrm{~Hz}, \mathrm{OH}-4), 4.73$ (d, $1 \mathrm{H}, J=5.8 \mathrm{~Hz}, \mathrm{OH}-3)$, $4.70(\mathrm{~d}, 1 \mathrm{H}, J=3.2 \mathrm{~Hz}, \mathrm{H}-1), 4.66(\mathrm{~d}, 1 \mathrm{H}, J=12.3 \mathrm{~Hz}$, $\left.\mathrm{CH}_{2} \mathrm{~b}-\mathrm{Ph}\right), 4.54(\mathrm{t}, 1 \mathrm{H}, J=5.8 \mathrm{~Hz}, \mathrm{OH}-6), 4.41(\mathrm{~d}, 1 \mathrm{H}$, $\left.J=12.3 \mathrm{~Hz}, \mathrm{CH}_{2} \mathrm{a}-\mathrm{Ph}\right), 3.68(\mathrm{~m}, 1 \mathrm{H}, \mathrm{H}-2), 3.65(\mathrm{~m}, 1 \mathrm{H}$, H-6b), 3.53 (m, 1H, H-3), 3.50 (m, 1H, H-6a), 3.45 (m, $1 \mathrm{H}, \mathrm{H}-5), 3.16(\mathrm{~m}, 1 \mathrm{H}, \mathrm{H}-4), 1.83\left(\mathrm{~s}, 3 \mathrm{H}, \mathrm{CH}_{3}-\mathrm{CON}\right.$ acetyl); ${ }^{13} \mathrm{C}$ NMR (DMSO- $\left.d_{6}\right) \delta /$ ppm: $169.4(\mathrm{CO}$ acetyl), 137.9 (Ph (C)), 128.1-127.4 (Ph(CH)), 95.9 (C-1), 73.1 (C-5), 70.9 (C-4), 70.6 (C-3), $67.7\left(\mathrm{CH}_{2}-\mathrm{Ph}\right), 60.8$ (C-6), 53.7 (C-2), 22.5 ( $\mathrm{CH}_{3}$-CON acetyl); MS-ESI $\mathrm{m} / \mathrm{z}$ $312[\mathrm{M}+\mathrm{H}]^{+}$.

Benzyl 2-acetamido-4,6-O-benzylidene-2-deoxy- $\alpha$-D-glucopyranoside $(3)^{21}$

Suspension of compound 2 (6 g, $0.019 \mathrm{~mol})$, benzaldehyde $(100 \mathrm{~mL})$ and anhydrous $\mathrm{ZnCl}_{2}(6 \mathrm{~g})$ was stirred at room temperature for $16 \mathrm{~h}$. Solution was spilt in icecold water-petrol ether mixture $(80 \mathrm{~mL}$ : $60 \mathrm{~mL})$. Solution was mixed for additional $15 \mathrm{~min}$, after which the formed precipitate was filtrated, washed with water and hexane. Crude product was recrystallized from mixture of 2-propanol $(50 \mathrm{~mL})$ and dioxane $(20 \mathrm{~mL})$ and crystals were filtrated and washed with cold 2-propanol to give compound $3\left(6.1 \mathrm{~g}, 80 \%\right.$ yield). $R_{\mathrm{f}}(\mathrm{B})=0.72$; m.p. $240-242{ }^{\circ} \mathrm{C}$ (lit. $\left.263-264{ }^{\circ} \mathrm{C}\right)^{21} ;[\alpha]_{\mathrm{D}}=+110^{\circ} \mathrm{c} 1$, pyridine (lit. $[\alpha]_{\mathrm{D}}=+108{ }^{\circ} c 1$, pyridine) ${ }^{22} ;{ }^{1} \mathrm{H}$ NMR (DMSO- $\left.d_{6}\right) \delta / \mathrm{ppm}: 7.97$ (d, $\left.1 \mathrm{H}, J=8.3 \mathrm{~Hz}, \mathrm{NH}\right), 7.46-$ $7.30(\mathrm{~m}, 10 \mathrm{H}, \mathrm{Ph}), 5.62(\mathrm{~s}, 1 \mathrm{H}, C H-\mathrm{Ph}) 5.16(\mathrm{~d}, 1 \mathrm{H}$, $J=5.8 \mathrm{~Hz}, \mathrm{OH}-3), 4.80(\mathrm{~d}, 1 \mathrm{H}, J=3.6, \mathrm{H}-1), 4.69$ (d, $\left.1 \mathrm{H}, J=12.3 \mathrm{~Hz}, C H_{2} \mathrm{~b}-\mathrm{Ph}\right), 4.48(\mathrm{~d}, 1 \mathrm{H}, J=12.3 \mathrm{~Hz}$, $\left.\mathrm{CH}_{2} \mathrm{a}-\mathrm{Ph}\right), 4.14(\mathrm{~m}, 1 \mathrm{H}, \mathrm{H}-6 \mathrm{~b}), 3.84(\mathrm{~m}, 1 \mathrm{H}, \mathrm{H}-2)$, 3.74-7.71 (m, 2H, H-3, H-6a), 3.69 (m, 1H, H-5), 3.51
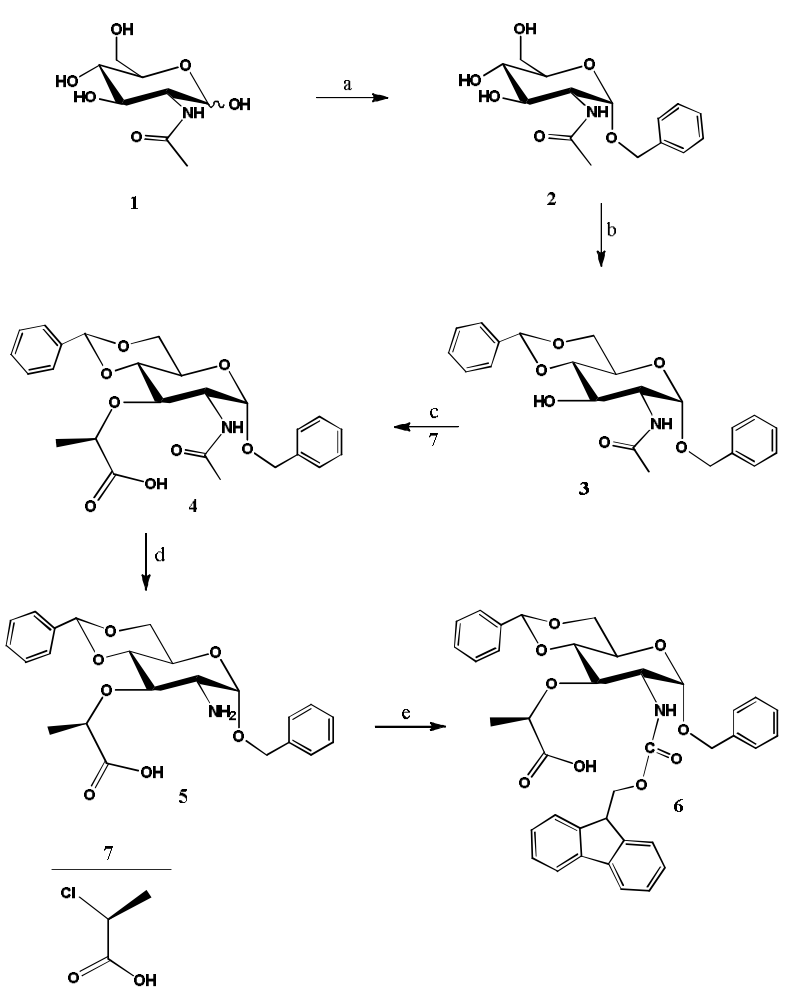

Figure 1. Synthesis of protected muramic derivative $\mathbf{6}$ from $N$-acetylglucosamine (1). Reagents and conditions: $\mathrm{BnOH}$, toluene, $p$-toluene sulfonic acid monohydrate, $130^{\circ} \mathrm{C}, 4 \mathrm{~h}$ (a); benzaldehyde, $\mathrm{ZnCl}_{2}, 16 \mathrm{~h}$ (b); $\mathrm{NaH}, 70{ }^{\circ} \mathrm{C}, 24 \mathrm{~h}$ (c); $5 \mathrm{M} \mathrm{KOH}$, $120{ }^{\circ} \mathrm{C}, 16 \mathrm{~h}$ (d); Fmoc-OSu, DMF, $\mathrm{NaHCO}_{3}, 0^{\circ} \mathrm{C}, 2 \mathrm{~h}(\mathrm{e})$. 
(t, $1 \mathrm{H}, J=8.8 \mathrm{~Hz}, \mathrm{H}-4), 1.84$ (s, 3H, $\mathrm{CH}_{3}-\mathrm{CON}$ acetyl); ${ }^{13} \mathrm{C}$ NMR (DMSO- $\left.d_{6}\right) \quad \delta / \mathrm{ppm}: 169.4$ (CO acetyl), $137.7(\mathrm{Ph}(\mathrm{C})), 129.2-126.4(\mathrm{Ph}(\mathrm{CH})), 100.8(\mathrm{CH}-\mathrm{Ph})$, 96.9 (C-1), 82.1 (C-4), $68.6\left(\mathrm{CH}_{2}-\mathrm{Ph}\right), 68.0$ (C-6), 67.2 (C-3), 62.8 (C-5), 54.2 (C-2), 22.5 ( $\mathrm{CH}_{3}$-CON acetyl); MS-ESI $m / z 400[\mathrm{M}+\mathrm{H}]^{+}$.

Benzyl 2-acetamido-4,6-O-benzylidene-3-O-[(R)-1-carboxyethyl]-2-deoxy- $\alpha$-D-glucopyranoside $(4)^{23}$

Compound $3(4 \mathrm{~g}, 0.010 \mathrm{~mol})$ was dissolved in anhydrous dioxane $(170 \mathrm{~mL})$ and stirred at $80-90^{\circ} \mathrm{C}$ until dissolved. The temperature was lowered to $70{ }^{\circ} \mathrm{C}$ and $\mathrm{NaH}$ (3.1 g, $0.130 \mathrm{~mol}, 80 \%$ oil dispersion) in small portions was added to solution. Reaction mixture was stirred for $1 \mathrm{~h}$ at $95{ }^{\circ} \mathrm{C}$ then cooled to $65{ }^{\circ} \mathrm{C}$, and solution of $(S)$-2-chloropropionic acid (7, $3.2 \mathrm{~g}, 0.030 \mathrm{~mol})$ in anhydrous dioxane $(10 \mathrm{~mL})$ was added dropwise. After $1 \mathrm{~h}$ stirring at $65^{\circ} \mathrm{C}$ the additional amount of $\mathrm{NaH}$ $(1.9 \mathrm{~g}, 0.080 \mathrm{~mol})$ was added and reaction mixture was stirred at $70{ }^{\circ} \mathrm{C}$ for $24 \mathrm{~h}$. Reaction mixture was cooled in ice-water bath and ice cold water was added dropwise. After the extraction upper light yellow layer was filtrated and dioxane was evaporated in vacuum to $30 \mathrm{~mL}$. The residue was dissolved in water $(50 \mathrm{~mL})$ and extracted with dichloromethane (DCM, $2 \times 20 \mathrm{~mL})$. Organic layer was washed with $20 \mathrm{~mL}$ water. Water layers were cooled to $0{ }^{\circ} \mathrm{C}$ and adjusted to $\mathrm{pH}=3(2 \mathrm{M} \mathrm{HCl})$ and stirred for $15 \mathrm{~min}$. The precipitated product was washed with ice cold water and evaporated. Crude product was purified by flash silica gel column chromatography in solvent system $\mathrm{C}$ to give compound 4 (3.7 $\mathrm{g}, 78 \%$ yield) white amorphous crystalline. $R_{\mathrm{f}}(\mathrm{D})=$ 0.52 ; m.p. $238-240{ }^{\circ} \mathrm{C}$ (lit. $\left.237-239{ }^{\circ} \mathrm{C}\right)^{22} ;[\alpha]_{\mathrm{D}}=$ $+133^{\circ} c 1, \mathrm{MeOH}\left(\text { lit. }[\alpha]_{\mathrm{D}}=+117^{\circ} c 0.5, \mathrm{MeOH}\right)^{22}$; ${ }^{1} \mathrm{H}$ NMR (DMSO- $\left.d_{6}\right) \delta / \mathrm{ppm}: 7.97(\mathrm{~d}, 1 \mathrm{H}, J=5.2 \mathrm{~Hz}$, $\mathrm{NH}), 7.42-7.30(\mathrm{~m}, 10 \mathrm{H}, \mathrm{Ph}), 5.70$ (s, 1H, CH-Ph), 5.04 (d, $1 \mathrm{H}, J=3.2 \mathrm{~Hz}, \mathrm{H}-1), 4.69$ (d, $1 \mathrm{H}, J=12.3 \mathrm{~Hz}$, $\left.\mathrm{CH}_{2} \mathrm{~b}-\mathrm{Ph}\right), 4.48\left(\mathrm{~d}, 1 \mathrm{H}, \mathrm{J}=12.3 \mathrm{~Hz}, \mathrm{CH}_{2} \mathrm{a}-\mathrm{Ph}\right), 4.28$ (q,1H, $J=6.9 \mathrm{~Hz}, \mathrm{CH}-\mathrm{CH}_{3}$ lactyl), 4.14 (m, 1H, H-6b), $3.80(\mathrm{~m}, 1 \mathrm{H}, \mathrm{H}-2), 3.77(\mathrm{~m}, 1 \mathrm{H}, \mathrm{H}-6 \mathrm{a}), 3.73(\mathrm{~m}, 1 \mathrm{H}$, H-3) 3.72 (m, 1H, H-2) 3.70 (m, 1H, H-5), 1.85 (s, 3H, $\mathrm{CH}_{3}-\mathrm{CON}$ acetyl), 1.27 (d, $3 \mathrm{H}, \mathrm{J}=6.9 \mathrm{~Hz}, \mathrm{CH}-\mathrm{CH}_{3}$ lactyl); ${ }^{13} \mathrm{C}$ NMR (DMSO- $\left.d_{6}\right) \delta / \mathrm{ppm}: 175.2(\mathrm{COOH})$, 169.3 (CO acetyl), $137.6(\mathrm{Ph}(C)), \quad 128.7-125.8$ $(\mathrm{Ph}(\mathrm{CH})), 100.2$ (CH-Ph), 96.8 (C-1), 81.5 (C-4), 75.1 (C-3), $75.0\left(\mathrm{CH}-\mathrm{CH}_{3}\right.$ lactyl), $68.9\left(\mathrm{CH}_{2}-\mathrm{Ph}\right), 67.8(\mathrm{C}-6)$, 62.9 (C-5), $53.5(\mathrm{C}-2), 22.6\left(\mathrm{CH}_{3}-\mathrm{CON}\right), 18.6\left(\mathrm{CH}-\mathrm{CH}_{3}\right.$ lactyl); MS-ESI $m / z 472[\mathrm{M}+\mathrm{H}]^{+}$.

Benzyl 2-amino-4,6-O-benzylidene-3-O-[(R)-1-carboxyethyl]-2-deoxy- $\alpha$-D-glucopyranoside (5) ${ }^{19}$

Compound 4 ( $2 \mathrm{~g}, 4.2 \mathrm{mmol})$ was dissolved in $5 \mathrm{M}$ $\mathrm{KOH}$ in ethanol $(28 \mathrm{~mL})$. Reaction mixture was stirred $16 \mathrm{~h}$ at $120{ }^{\circ} \mathrm{C}$ under nitrogen. Saturated solution of $\mathrm{NH}_{4} \mathrm{Cl}$ was added in reaction mixture and extracted with
DCM $(3 \times 50 \mathrm{~mL})$. Solvent was evaporated and crude product was purified on flash silica gel column chromatography using solvent system $\mathrm{E}$ to elute impurities and solvent system $\mathrm{C}$ to give compound $5(1.46 \mathrm{mg}, 81 \%$ yield). $R_{\mathrm{f}}(\mathrm{E})=0.52 ;$ m.p. $175-176{ }^{\circ} \mathrm{C} ;[\alpha]_{\mathrm{D}}=+128^{\circ}$ $c 1, \mathrm{MeOH} ;{ }^{1} \mathrm{H}$ NMR (DMSO- $\left.d_{6}\right) \delta / \mathrm{ppm}: 7.97$ (d, $1 \mathrm{H}$, $\left.J=5.2 \mathrm{~Hz}, \mathrm{NH}_{2}\right), 7.43-7.30(\mathrm{~m}, 10 \mathrm{H}, \mathrm{Ph}), 5.68(\mathrm{~s}, 1 \mathrm{H}$, CH-Ph), 5.08 (d, 1H, J=3.7 Hz, H-1), 4.69 (d, 1H, $\left.J=11.8 \mathrm{~Hz}, \mathrm{CH}_{2} \mathrm{~b}-\mathrm{Ph}\right), 4.57$ (d, $1 \mathrm{H}, J=11.8 \mathrm{~Hz}, \mathrm{CH}_{2} \mathrm{a}-$ $\mathrm{Ph}), 4.11$ (m, 1H, H-6a), 3.91 (q, 1H, J=7.0 Hz, CH$\mathrm{CH}_{3}$ lactyl), 3.72 (m, 1H, H-6b), 3.66 (m, 1H, H-4) 3.63 (m, 1H, H-5), 3.61 (m, 1H, H-3), $3.11(\mathrm{~m}, 1 \mathrm{H}, \mathrm{H}-2)$, $1.22\left(\mathrm{~d}, 3 \mathrm{H}, J=6.9 \mathrm{~Hz}, \mathrm{CH}-\mathrm{CH}_{3}\right.$ lactyl); ${ }^{13} \mathrm{C} \mathrm{NMR}$ $\left(\mathrm{DMSO}-d_{6}\right) \delta / \mathrm{ppm}: 175.7(\mathrm{COOH}), 137.3(\mathrm{Ph}(C))$, 128.8-125.8 (Ph(CH)), $100.2(\mathrm{CH}-\mathrm{Ph}), 96.8(\mathrm{C}-1), 80.9$ (C-4), $78.6\left(\mathrm{CH}-\mathrm{CH}_{3}\right.$ lactyl), $76.8(\mathrm{C}-3), 69.4\left(\mathrm{CH}_{2}-\mathrm{Ph}\right)$, 67.6 (C-6), 62.9 (C-5), 53.4 (C-2), 19.3 (CH- $\mathrm{CH}_{3}$ lactyl); MS-ESI $m / z 430[\mathrm{M}+\mathrm{H}]^{+}$; HRMS calcd. for $\mathrm{C}_{23} \mathrm{H}_{28} \mathrm{NO}_{7} 430.1860$ found: 430.1849 .

Benzyl 2-amino-4,6-O-benzylidene-3-O-[(R)-1-carboxyethyl] - 2-deoxy-N-9-fluorenylmethyloxycarbonyl- $\alpha-D-$ glucopyranoside (6)

Compound 5 ( $1 \mathrm{~g}, 2.3 \mathrm{mmol}$ ) was dissolved in DMF (20 $\mathrm{mL})$ and sodium hydrogen carbonate (392 mg, 2 eq.) in water $(20 \mathrm{~mL})$ was added. Reaction mixture was kept at $0{ }^{\circ} \mathrm{C}$ and cold solution of Fmoc $N$-hydroxysuccinimide ester (Fmoc-OSu, $865 \mathrm{mg}, 1.1$ eq.) in DMF (20 mL) was added dropwise. Reaction was stirred in ice-water bath for $2 \mathrm{~h}$. Water $(100 \mathrm{~mL})$ was added to the reaction mixture and formed precipitate was filtrate and washed with water. Product was evaporated under vacuum and then purified on flash silica gel column in solvent system $\mathrm{C}$ which gave $1.35 \mathrm{~g}$ (90\% yield) of compound 6 . $R_{\mathrm{f}}(\mathrm{C})=0.48 ;$ m.p. $179-180{ }^{\circ} \mathrm{C} ;[\alpha]_{\mathrm{D}}=+71^{\circ} \mathrm{c} 1$, DMF; ${ }^{1} \mathrm{H}$ NMR (DMSO- $\left.d_{6}\right) \delta / \mathrm{ppm}: 7.95(\mathrm{NH}), 7.91-7.89$ (m, 2H, Fmoc), 7.75-7.71 (m, 2H, Fmoc), 7.43-7.28 (m, 10H, Ph; 2H, Fmoc), 7.22-7.20 (m, 2H, Fmoc) 5.69 (s, 1H,CH-Ph), 5.21 (d, 1H, J=3.1 Hz, H-1), 4.69 (d, $\left.1 \mathrm{H}, J=12.4 \mathrm{~Hz}, \mathrm{CH}_{2} \mathrm{~b}-\mathrm{Ph}\right), 4.48(\mathrm{~d}, 1 \mathrm{H}, J=12.4 \mathrm{~Hz}$, $\left.\mathrm{CH}_{2} \mathrm{a}-\mathrm{Ph}\right), 4.23$ (m, $\left.\mathrm{CH}_{2} \mathrm{~b}-\mathrm{CH}-\mathrm{Fmoc}\right), 4.22$ (m, $\mathrm{CH}$-Fmoc), 4.15 (m, 1H, H-6a), 4.11 (m, $\mathrm{CH}_{2} \mathrm{a}-\mathrm{CH}-$ Fmoc), $4.10\left(\mathrm{q}, 1 \mathrm{H}, J=7.0 \mathrm{~Hz}, \mathrm{CH}-\mathrm{CH}_{3}\right.$ lactyl), 3.79 (m, 1H, H-6b), 3.85 (m, 1H, H-3) 3.77 (m, 1H, H-4) $3.71(\mathrm{~m}, 1 \mathrm{H}, \mathrm{H}-5), 3.44(\mathrm{~m}, 1 \mathrm{H}, \mathrm{H}-2), 1.26(\mathrm{~d}, 3 \mathrm{H}$, $J=7.4 \mathrm{~Hz}, \mathrm{CH}-\mathrm{CH}_{3}$ lactyl); ${ }^{13} \mathrm{C}$ NMR (DMSO-d $)$ $\delta /$ ppm: $177.2(\mathrm{COOH}), 156.4$ (CO Fmoc), 143.8 (Fmoc (C)), 140.6 (Fmoc (C)), 137.7 (Ph (C)), 128.9-125.3 (Ph $(\mathrm{CH})$ ), 120.1-120.0 (Fmoc $(\mathrm{CH})), 100.21$ ( $\mathrm{CH}-\mathrm{Ph})$, 96.7 (C-1), 82.56 (C-4), $77.5\left(\mathrm{CH}-\mathrm{CH}_{3}\right.$ lactyl), 72.8 (C-3), $68.8\left(\mathrm{CH}_{2}-\mathrm{Ph}\right), 67.9$ (C-6), 65.8 ( $\mathrm{CH}_{2}-\mathrm{CH}$ Fmoc), 63.1 (C-5), 55.8 (C-2), $46.6\left(\mathrm{CH}_{2}-\mathrm{CH}\right.$ Fmoc), 19.3 (CH- $\mathrm{CH}_{3}$ lactyl); MS-ESI $\mathrm{m} / z$ $674[\mathrm{M}+\mathrm{Na}]^{+}$; HRMS calcd. for $\mathrm{C}_{38} \mathrm{H}_{37} \mathrm{NO}_{9} \mathrm{Na} 674.2360$ found: 674.2372 . 
Table 1. NMR data ( $\delta$ in ppm) of compounds 4-6 in DMSO- $d_{6}$

\begin{tabular}{|c|c|c|c|c|c|c|}
\hline \multirow{2}{*}{ Position } & \multicolumn{3}{|c|}{${ }^{1} \mathrm{H}$ NMR } & \multicolumn{3}{|c|}{${ }^{13} \mathrm{C}$ NMR } \\
\hline & 4 & 5 & 6 & 4 & 5 & 6 \\
\hline $\mathrm{CH}-1$ & 5.04 & 5.08 & 5.21 & 96.8 & 96.8 & 96.7 \\
\hline $\mathrm{CH}-2$ & 3.80 & 3.11 & 3.44 & 53.5 & 53.4 & 55.8 \\
\hline $\mathrm{CH}-3$ & 3.73 & 3.61 & 3.85 & 75.1 & 76.8 & 72.8 \\
\hline $\mathrm{CH}-4$ & 3.72 & 3.66 & 3.77 & 81.5 & 80.9 & 82.6 \\
\hline $\mathrm{CH}-5$ & 3.70 & 3.63 & 3.71 & 62.9 & 62.9 & 63.1 \\
\hline $\mathrm{CH}-6 \mathrm{a}$ & 3.77 & 3.72 & 3.79 & 67.8 & 67.6 & 67.9 \\
\hline CH-6b & 4.14 & 4.11 & 4.15 & - & - & - \\
\hline $\mathrm{CH}-\mathrm{CH}_{3}$ & 4.28 & 3.91 & 4.10 & 75.0 & 78.6 & 77.5 \\
\hline $\mathrm{CH}-\mathrm{CH}_{3}$ & 1.27 & 1.22 & 1.26 & 18.6 & 19.3 & 19.3 \\
\hline $\mathrm{CH}_{3}-\mathrm{CON}$ & 1.85 & & & 22.6 & & \\
\hline $\mathrm{CH}_{2} \mathrm{a}-\mathrm{Ph}$ & 4.48 & 4.57 & 4.48 & 68.9 & 69.4 & 68.8 \\
\hline $\mathrm{CH}_{2} b-\mathrm{Ph}$ & 4.69 & 4.69 & 4.69 & - & - & - \\
\hline $\mathrm{CH}-\mathrm{Ph}$ & 5.70 & 5.68 & 5.69 & 100.2 & 100.2 & 100.2 \\
\hline $\mathrm{Ph}(\mathrm{CH})$ & $7.30-7.42$ & $7.32-7.43$ & $7.28-7.43$ & $125.8-128.7$ & $125.8-128.8$ & $125.3-128.9$ \\
\hline $\operatorname{Ph}(C)$ & - & - & - & 137.6 & 137.3 & 137.7 \\
\hline $\mathrm{NH}$ & 7.97 & 7.97 & 7.95 & - & - & - \\
\hline $\mathrm{CON}$ & - & - & - & 169.3 & - & - \\
\hline $\mathrm{COOH}$ & - & - & - & 175.2 & 175.7 & 177.2 \\
\hline CO-Fmoc & - & - & - & - & - & 156.4 \\
\hline $\operatorname{Fmoc}(C)$ & & & & & & $140.6 ; 143.8$ \\
\hline Fmoc $(\mathrm{CH})$ & & & $\begin{array}{l}7.71-7.91 \\
7.20-7.22\end{array}$ & & & $120.0-120.1$ \\
\hline $\mathrm{CH}_{2} \mathrm{a}-\mathrm{CH}$ Fmoc & & & 4.11 & & & 65.8 \\
\hline $\mathrm{CH}_{2} b-\mathrm{CH}$ Fmoc & & & 4.23 & & & - \\
\hline $\mathrm{CH}_{2}-\mathrm{CH}$ Fmoc & & & 4.22 & & & 46.6 \\
\hline
\end{tabular}

(S)-2-Chloropropionic acid (7) ${ }^{24}$

L-Alanine (6 g, $0.067 \mathrm{~mol})$ was dissolved in $8 \mathrm{M} \mathrm{HCl}$ $(84 \mathrm{~mL})$ and cooled to $0{ }^{\circ} \mathrm{C}$ and then solution of $\mathrm{NaNO}_{2}$ ( $7.6 \mathrm{~g}$ in $24 \mathrm{~mL}$ water) in water was added dropwise with vigorous stirring. Temperature was kept at $5{ }^{\circ} \mathrm{C}$ for $2 \mathrm{~h}$, and after that the reaction mixture was stirred at $2{ }^{\circ} \mathrm{C}$ for additional $4 \mathrm{~h}$, and overnight at room temperature in inert conditions (under nitrogen). Sodium hydrogen carbonate $(6.6 \mathrm{~g})$ was added to the reaction mixture in small portions with vigorous stirring. Reaction was extracted with ether $(2 \times 50 \mathrm{~mL}, 1 \times 30 \mathrm{~mL})$ and collected ether's extracts were washed with saturated solution of calcium chloride $(20 \mathrm{~mL})$ and re-extracted with ether $(30 \mathrm{~mL})$. Ether's extracts were dried for $2 \mathrm{~h}$ on calcium chloride. Ether was evaporated under reduced pressure and oil residue was distilled in vacuum to give pure $(S)$-2-chloropropionic acid (5.3 g, $73 \%$ yield). b.p. $89^{\circ} \mathrm{C}$ at $p=2.66 \mathrm{kPa} ;[\alpha]_{\mathrm{D}}=-16.3^{\circ}$ (lit. $[\alpha]_{\mathrm{D}}=$ $\left.-13.98{ }^{\circ}\right)^{24} ;{ }^{1} \mathrm{H}$ NMR $\left(\mathrm{CDCl}_{3}\right) \delta / \mathrm{ppm}: 1.74(\mathrm{~d}, 3 \mathrm{H}$,$) ,$ $4.45(\mathrm{q}, 1 \mathrm{H}),, 10.5(\mathrm{~s}, 1 \mathrm{H}) ;{ }^{13} \mathrm{C} \mathrm{NMR}\left(\mathrm{CDCl}_{3}\right) \delta / \mathrm{ppm}$ : 21.3; 52.1; 176.0; MS-ESI $m / z$ 153.1 $[\mathrm{M}+2 \mathrm{Na}]^{2+}(100 \%)$; $155.0[\mathrm{M}+2+2 \mathrm{Na}]^{2+}(32 \%)$.

\section{RESULTS AND DISCUSSION}

The first three reaction steps were part of the established synthesis of $N$-acetylmuramic acid. ${ }^{25-29}$ The synthesis started from $N$-acetylglucosamine $\mathbf{1}$, which was protected by benzylation with benzyl alcohol at the anomeric position. ${ }^{19}$ The $p$-toluene sulfonic acid was used as a catalyst in the reaction which was carried out in toluene. The synthesis resulted in a $\alpha / \beta$ mixture of benzyl anomer $\mathbf{2}$, however the pure benzyl $\alpha$-anomer $\mathbf{2}$ can be obtained with thermodynamic control of the reaction by high temperature in refluxing toluene. ${ }^{29}$ The incorporation of a benzylidene protection group in the 4-O and 
6-O-hydroxy positions was carried out according to previously published Gross and Jeanloz strategy to afford protected $\mathrm{N}$-acetylglucosamine derivative $\mathbf{3}$ with a free 3-hydroxy group. ${ }^{21}$ The method for the efficient and easy synthesis of 4,6-benzylidne-derivative of $\mathrm{N}$-acetylglucosamine, using pyridinium perchlorate as catalyst in the reaction with benzaldehyde dimethylacetal, was recently published. ${ }^{30}$ By treating 3 with optically pure $(S)$-2-chloropropionic acid 7, the Williamson stereoselective ether synthesis proceeded in good yield (78 \%), to afford $4 .^{31}$ The synthesis of muramic acid previously reported in the literature is based on condensation of D-glucosamine derivatives with a 2-halogenopropionic acid derivative, forming an ether link with the hydroxyl group at C-3. ${ }^{23,31}$ In most of these approaches, methyl 2 -acetamido-4,6- $O$-benzylidene-2-deoxy- $\alpha$-Dglucopyranoside or benzyl 2-acetamido-4,6- $O$-benzylidene-2-deoxy- $\alpha$-D-glucopyranoside (3) have been used as a starting material. However, alkylation of the unprotected 3-O group of $\mathbf{3}$ with racemic 2-halogeno-propionic acid derivatives led to the formation of a mixture of epimeric $(R)$ and $(S)$ ethers (muramic and isomuramic acid derivatives), and the described methods require additional separation of the epimeric mixture in order to obtain pure diastereomers. ${ }^{32}$ Improvement in the synthesis of muramic acid was achieved by the use of enantiopure $(S)$-2-chloropropionic acid 7 as the alkylation agent in the critical condensation step. ${ }^{23}$ It was found that when $(S)$-2-chloropropionic acid was condensed with an alkoxide, it underwent Walden inversion. ${ }^{33}$ Therefore, the condensation of $\mathbf{3}$ with pure $(S)$-2-chloropropionic acid led stereospecifically to muramic acid, with $(R)$ configuration of the lactic acid moiety. Although this method avoids chromatographic separation of 4 , it was not explored due to the difficult preparation of optically pure reagent. ${ }^{32}$ Our modified approach for $(S)$-2-chloropropionic acid synthesis from $(S)$-alanine ${ }^{24}$ resulted in the optically pure compound 7 in $73 \%$ yield. The introduction of lactic acid moiety was achieved in presence of $\mathrm{NaH}$ according to the paper published by Sinaÿ et al. for the synthesis of manno derivative of muramic acid with some modification in time, temperature and purification of compound. ${ }^{34}$ The compound 4 was purified by flash chromatography and the stereoselectivity of the reaction was determined by ${ }^{1} \mathrm{H}$ NMR. The benzylidene proton at $5.68 \mathrm{ppm}$ for the muramic acid derivative $\mathbf{4}$ is indicative of the muramic acid derivative with the $(R)$-configuration of the lactyl sidechain according to the published data by Babič and Pečar which are for the muramic acid $5.66 \mathrm{ppm}$ and for the isomuramic acid $5.55 \mathrm{ppm} .{ }^{29}$ The determination of the absolute configuration was especially important in the next step in the reaction of saponification of the compound 4, to deprotect amino group and give compound 5 . This reaction conditions enable racemisation.

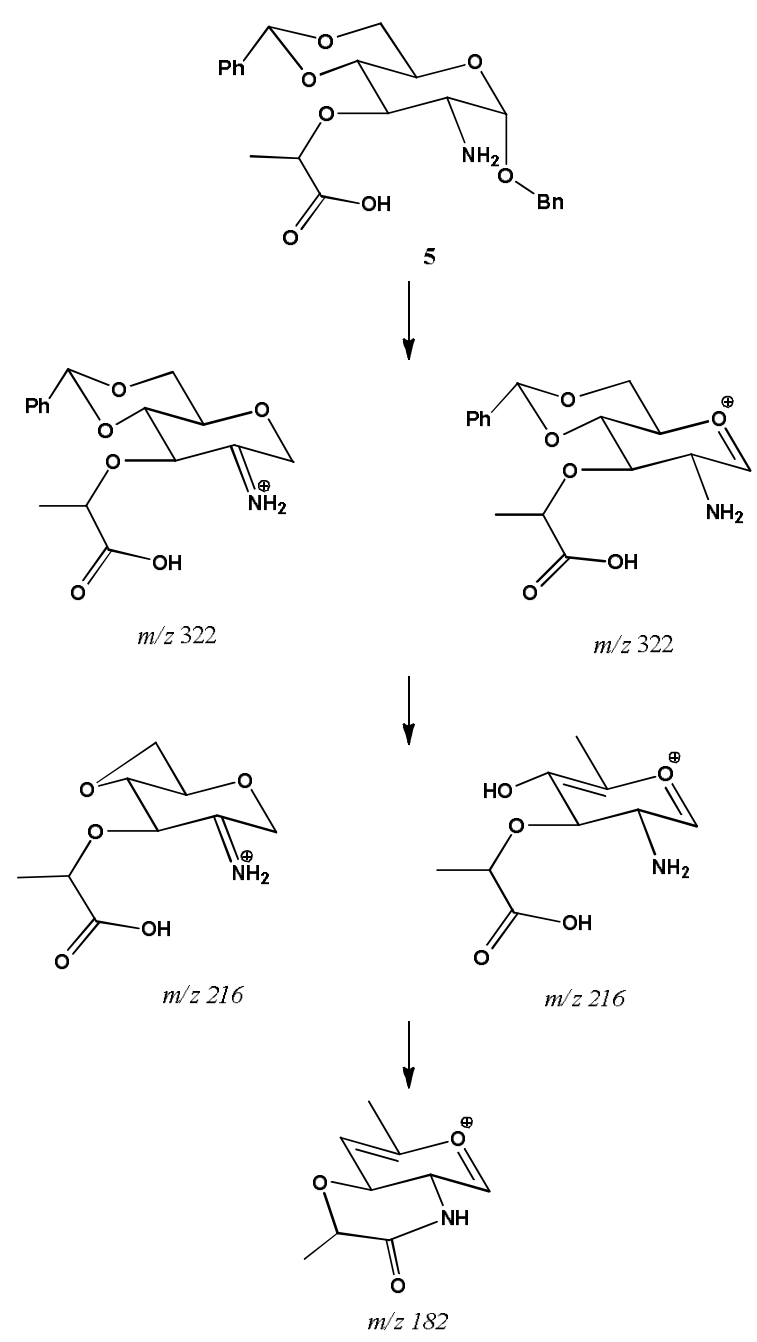

Figure 2. Fragmentation pattern of compound $\mathbf{5}$.

${ }^{1} \mathrm{H}$ NMR analysis shows benzylidene proton of compound 5 at 5.68 ppm (Table 1) which in comparison to compound 4 showed that we did not lose the optical purity in compound $\mathbf{5}$ with the $(R)$ configuration of the lactyl group. The introduction of the Fmoc protecting group, the major group that enables utilisation of muramic acid in SPPS, was obtained with Fmoc-OSu in $\mathrm{DMF} /$ water solvent mixture with sodium hydrogen carbonate under low temperature $\left(0^{\circ} \mathrm{C}\right)$ to avoid byproducts formation. The synthesis with $\mathrm{Fmoc}-\mathrm{Cl}$ as reagent was also examined but the reaction yields were poor. Upon the completion of the reaction the product 6 was precipitated with water, filtrated and purified on silica gel column in solvent system C. The optical purity was confirmed by ${ }^{1} \mathrm{H}$ NMR analysis which shows single signal for benzylidene proton of compound $\mathbf{6}$ at $5.69 \mathrm{ppm}$ (Table 1) which is in agreement with chemical shifts of compound 4 (5.70 ppm, Table 1) and compound 5 (5.68 ppm, Table 1), respectively, for $(R)$-configuration of the lactyl group. Synthesised Fmoc protected muramic acid can be used in SPPS as 

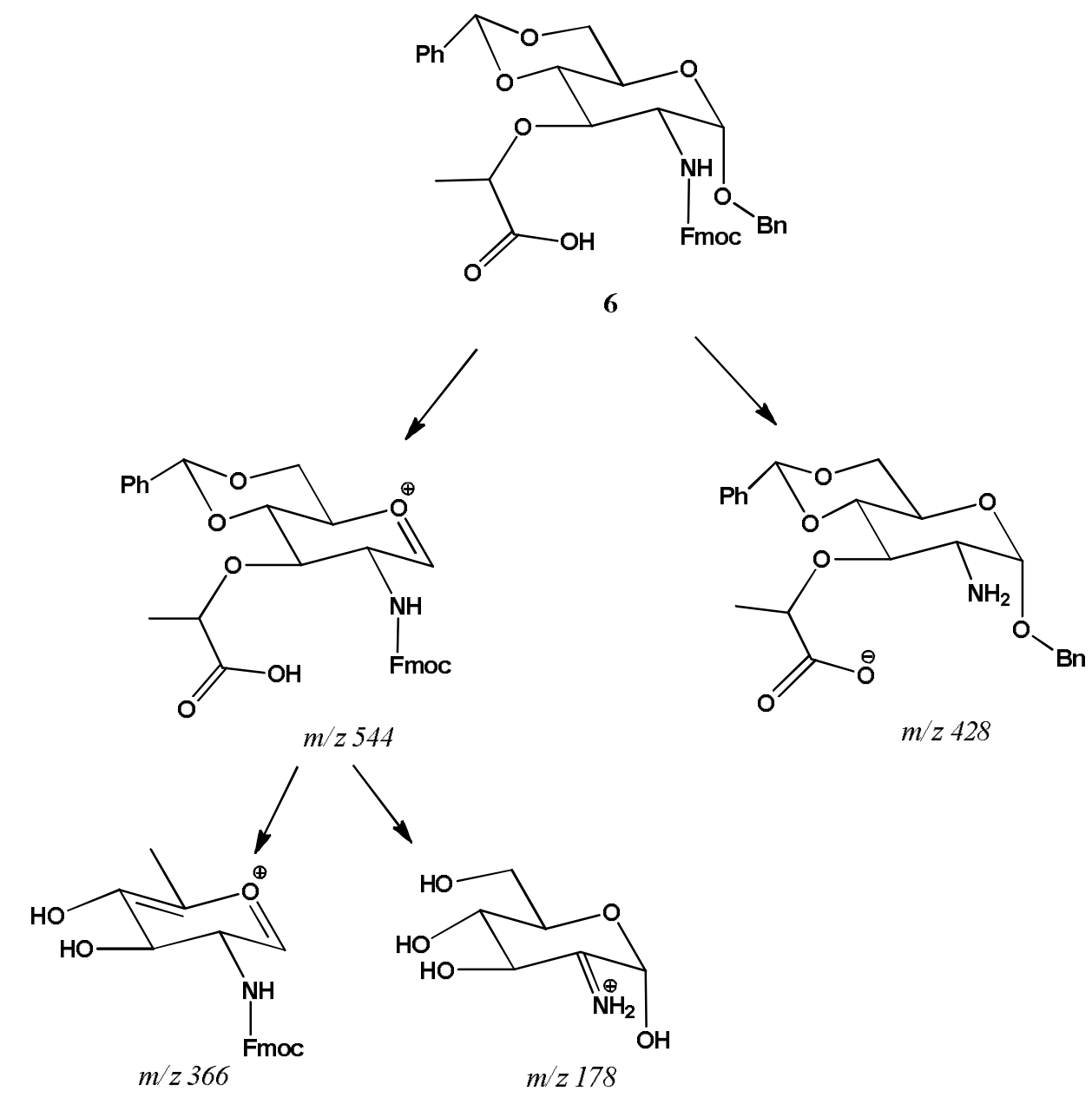

Figure 3. Fragmentation pattern of compound $\mathbf{6}$.

dipeptide isostere building block. Protecting groups are necessary during the synthesis especially for synthesis of longer peptides to avoid by-products formation and to facilitate product purification. Orthogonal protection of muramic acid allows removal of Fmoc protecting group during peptide synthesis, while benzylidene group and benzyl protecting group can be easily removed after peptide condensation under acidic conditions and catalytic hydrogenolysis.

\section{MS/MS fragmentation of prepared compounds}

Electrospray ionization (ESI) as soft-ionization method was used to determine the mass spectrometric properties of prepared compounds. The MS/MS fragmentation of all synthesised compounds from 2-6 showed the same tendency. The elimination of benzyl protecting group from 1-O of compounds 2-6 was confirmed with following detected fragments 204 (2), 292 (3), 364 (4), 322 (5, Figure 2) and 544 (6, Figure 3) Da, for each compound, respectively. ${ }^{35,36}$ The fragments 258 (4), 216 (5, figure 2) and 366 (6, Figure 3) Da are results of benzylidene protecting group elimination. Further most intense signal in MS/MS spectrum of compound $\mathbf{5}$ is 182 which response to the lactone structure shown on Figure 2. Fragmentation of compound $\mathbf{6}$ in positive mode completely differs from that one in negative mode. While positive mode shows the elimination of protecting groups as well as dehydration of molecule, in negative mode the main and only observed fragment was $428 \mathrm{Da}$ which responding to the Fmoc deprotected molecule (Figure 3).

\section{CONCLUSION}

In this work we reported simple and efficient synthesis of orthogonally protected muramic acid suitable for Fmoc solid-phase peptide synthesis. The advantages of our approach include simplified synthesis, use of readily available starting materials and high yield $(\sim 70-90 \%)$ of desired optically pure $(R)$-isomers of products $4-6$. The described synthesis of orthogonally protected muramic acid building blocks will allow an access to a variety of linear and cyclic peptides with unique structural properties and consequently biological activities. 
Supplementary Materials. - Supporting information to the paper is enclosed to the electronic version of the article.

Acknowledgements. We gratefully acknowledge the financial support of the NATO Public Diplomacy Division, Science for Peace and Security Programme (SfP 983154) and Ministry of Science, Education and Sport of the Republic of Croatia (0980982933-2936). The authors thank also prof. M. Cudic and prof. P. Cudic for useful suggestions and comments.

\section{REFERENCES}

1. S. A. W. Gruner, E. Locardi, E. Lohof, and H. Kessler, Chem. Rev. 102 (2002) 491-514.

2. F. Schweizer, Angew. Chem. Int. Ed. 41 (2002) 230-253.

3. T. K. Chakraborty, S. Ghosh, and S. Jayaprakash, Curr. Med. Chem. 9 (2002) 421-435.

4. T. K. Chakraborty, S. Jayaprakash, and S. Ghosh, Comb. Chem. High T. Scr. 5 (2002) 373-387.

5. J. Gervay-Hague and T. M. Jr. Weathers, J. Carbohydr. Chem. 21 (2002) 867-910.

6. T. K. Chakraborty, P. Srinivasu, S. Tapadar, and B. K. Mohan, J. Chem. Sci. 116 (2004) 187-207.

7. K. J. Jensen and J. Brask, Biopolymers 80 (2005) 747-761.

8. M. R. J. Salton, Microbial Cell Walls, Wiley, New York, 1960, pp. $39-42$.

9. F. Ellouz, A. Adam, R. Ciobvaru, and E. Lederer, Biochem. Biophys. Res. Commun. 59 (1974) 1317-1325.

10. L. Habjanec, B. Halassy, and J. Tomašić, Int. Immunopharmacol. 10 (2010) 751-759.

11. F. Coulombe, S. Fiola, S. Akira, Y. Cormier, and J. Gosselin, PLoS 14 (2012) e36734.

12. A. B. III Smith, S. Sasho, B. A. Barwis, P. Sprengeler, J. Barbosa, R. Hirschmann, and B. S. Cooperman, Bioorg. Med. Chem. Lett. 8 (1998) 3133-3136.

13. L. Poitout, Y. Le Merrer, and J. Depezay, Tetrahedron Lett. 36 (1995) 6887-6890.

14. J. P. McDevitt and P. T. Jr. Lansbury, J. Am. Chem. Soc. 118 (1996) 3818-3828.

15. N. L. Hungerford, T. D. W. Claridge, M. P. Watterson, R. T.
Aplin, A. Moreno, and G. W. J. Fleet, J. Chem. Soc., Perkin Trans. 1 (2000) 3666-3679.

16. M. Raunkjær, F. El Oualid, G. A. van der Marel, H. S. Overkleeft, and M. Overhand, Org. Lett. 6 (2004) 3167-3170.

17. A. A. Edwards, G. J. Sanjayan, S. Hachisu, R. Soengas, A. Stewart, G. E. Tranter, and G. W. J. Fleet, Tetrahedron 62 (2006) 4110-4119.

18. B. Lastdrager, M. S. M. Timmer, G. A. van der Marel, H. S. Overkleeft, and M. Overhand J. Carbohydr. Chem. 26 (2007) $41-59$.

19. R. Enugala, M. Manuel, and B. Marques, ARKIVOC (2012) (vi) 90-100.

20. M. L. Shulman and A. Ya Khorlin, Carbohydr. Res. 27 (1973) 141-147.

21. P. H. Gross and R.W. Jeanloz, J. Org. Chem. 32 (1967) 27592763.

22. P. H. Gross and M. Rimpler, Liebigs Ann. Chem. (1986) 37-45.

23. Y. Matsushima and J. T. Park, J. Org. Chem. 27 (1962) 35813583.

24. B. Koppenhoefer and V. Schurig in: G. N. Reddy, J. D. White (Eds), Org. Synth., Coll., Vol. 8, Organic Syntheses, Inc., 1993, p1 19.

25. R. Lambert and F. Zilliken, Chem. Ber. 93 (1960) 2915-2923.

26. R. Gigg and P. M. Carroll, Nature 191 (1961) 495-496.

27. H. M. Flowers and R. W. Jeanloz, J. Org. Chem. 28 (1963) 1564-1467.

28. T. Osawa and R.W. Jeanloz, J. Org. Chem. 30 (1965) 448-450.

29. A. Babič and S. Pečar, Tetrahedron-Asymmetr. 19 (2008) 22652271.

30. S. S. Pertel, S. A. Gunchak, E. S. Kakayan, V. Y. Chirva, and S. Vidal, 2-Acetamido-4,6-O-benzylidene-2-deoxy-D-glucopyranose, in: P. Kováč (Ed.), Carbohydrate Chemistry: Proven Synthetic Methods, CRC Press, Vol. 1, Chap. 21, 2011, pp 199-203.

31. D. Craig, J. P. Tierney, and C. Williamson, Tetrahedron Lett. 38 (1997) 4153-4156.

32. V. Ragoussis, L. Leondiadis, E. Livaniou, and J. P. Evangelatos, Carbohydr. Res. 297 (1997) 289-295.

33. E. D. Hugges, C. K. Ingold, R. J. L. Martin and D. F. Meigh, Nature 166 (1950) 679-680.

34. P. Sinaÿ, M. D. A. Halford, M. S. Choudhary, P. H. Gross, and R. W. Jeanloz, J. Biol. Chem. 247 (1972) 391-397.

35. Š. Horvat and A. Jakas, J. Peptide Sci. 10 (2004) 119-137.

36. I. Jerić, C. Verslius, Š. Horvat, and A. J. R. Heck, J. Mass Spectrom. 37 (2002) 803-811. 


\section{Compound 4:}

SpinWorks 2.5: Vlahovicek D477/mur

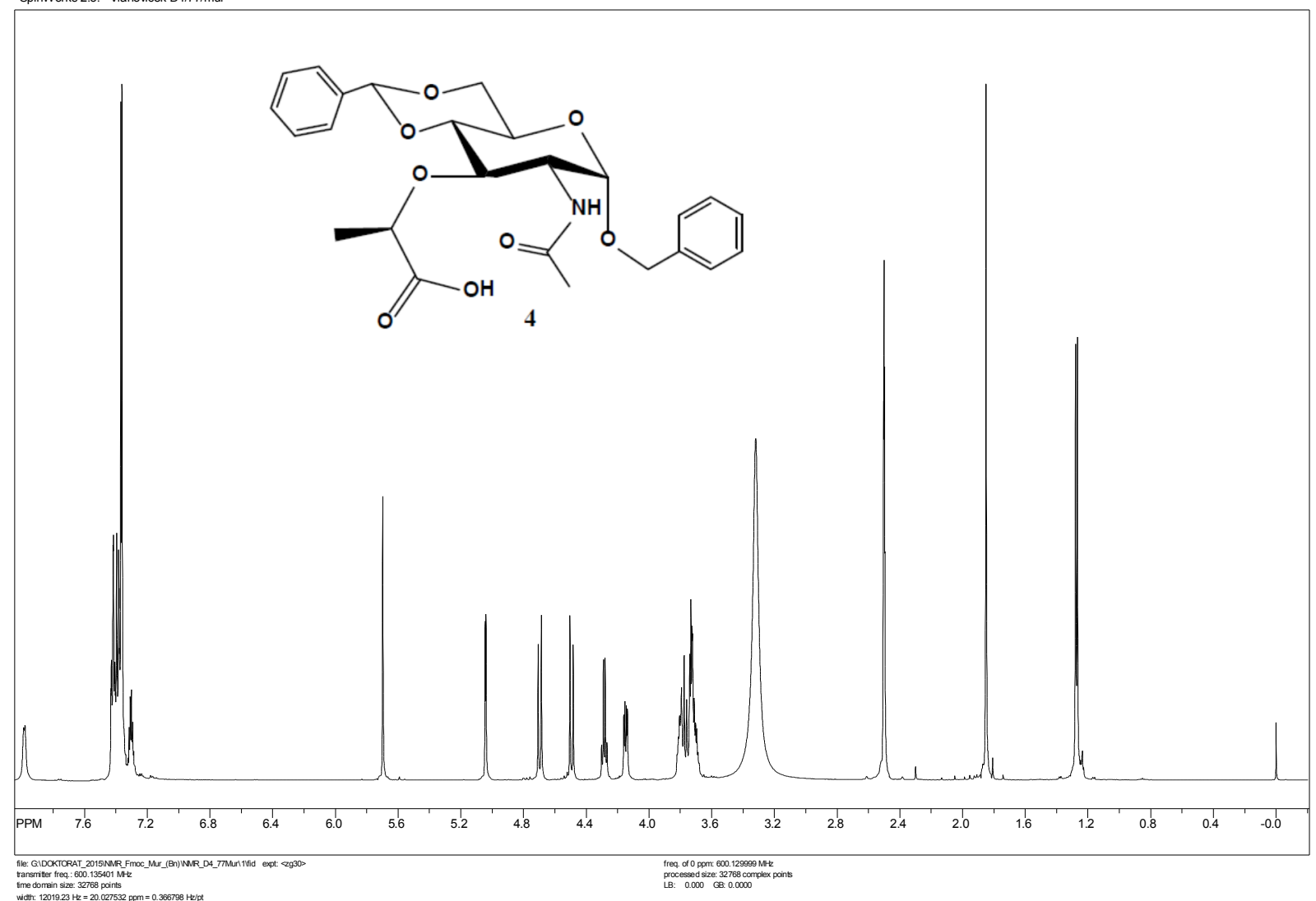

SpinWorks 2.5: Vlahovicek D4/77/mur

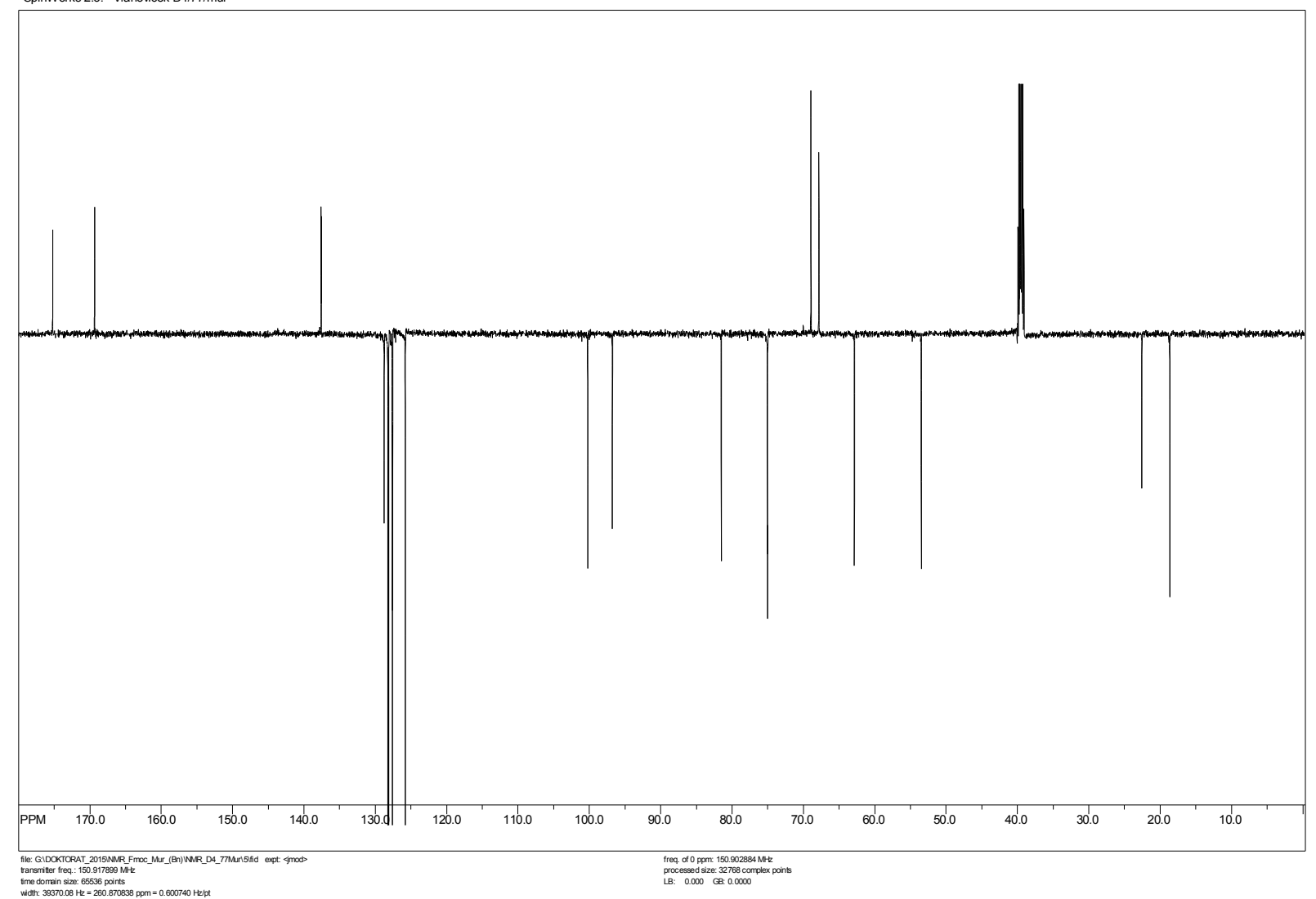




\section{Compound 5:}
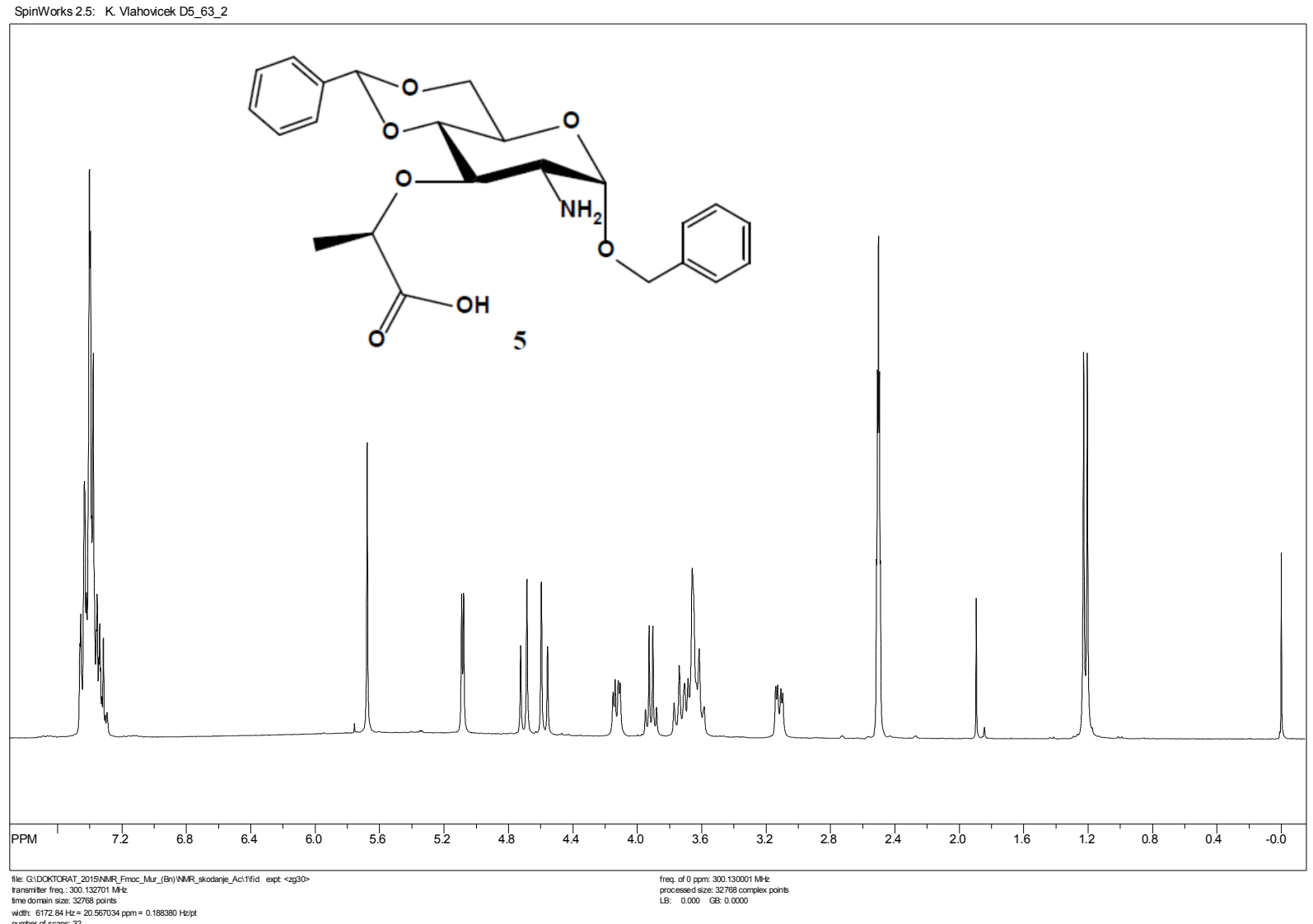

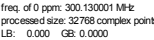
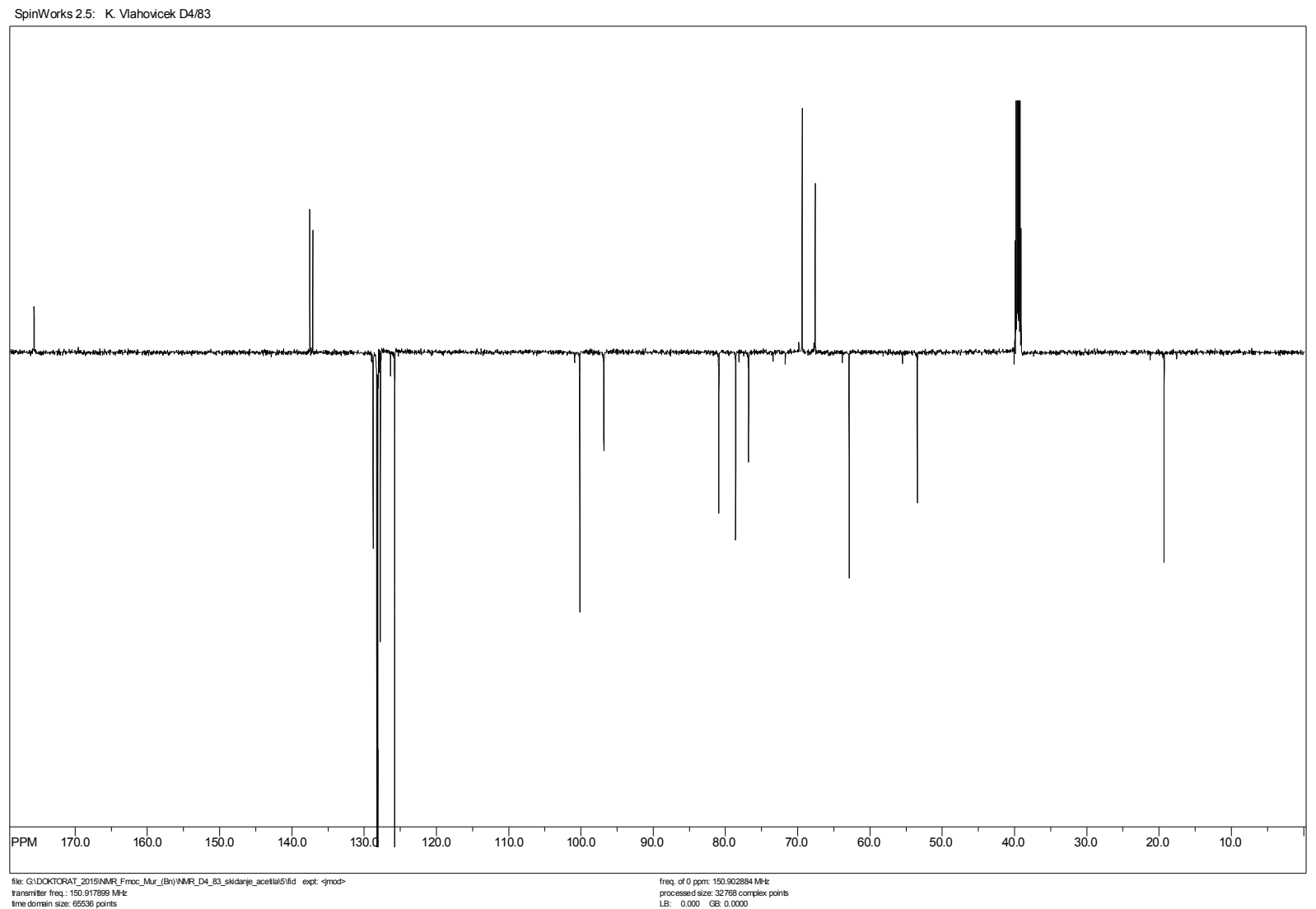


\section{Compound 6:}

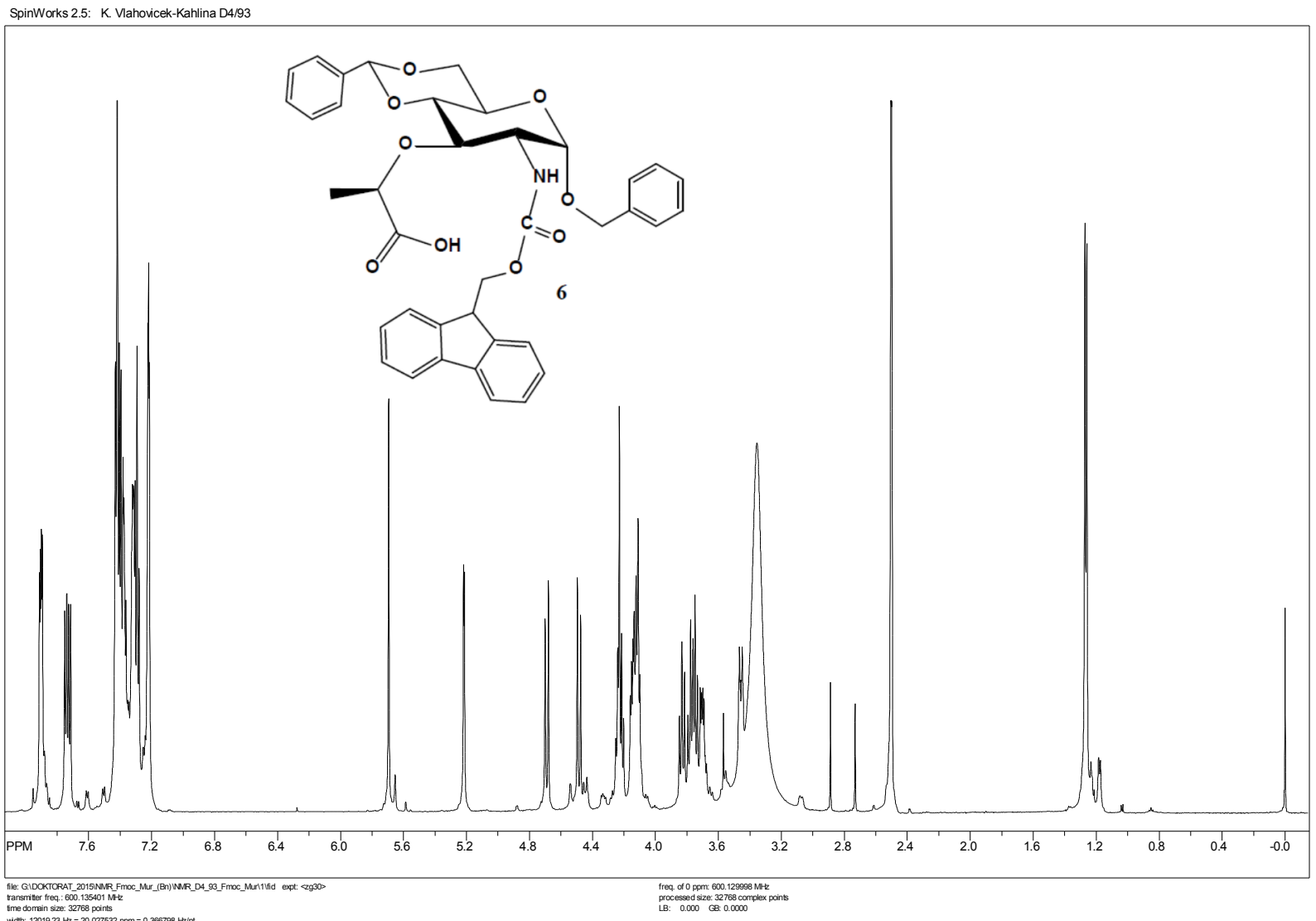

SpinWorks 2.5: K. Vahovicek-Kahlina D4/93

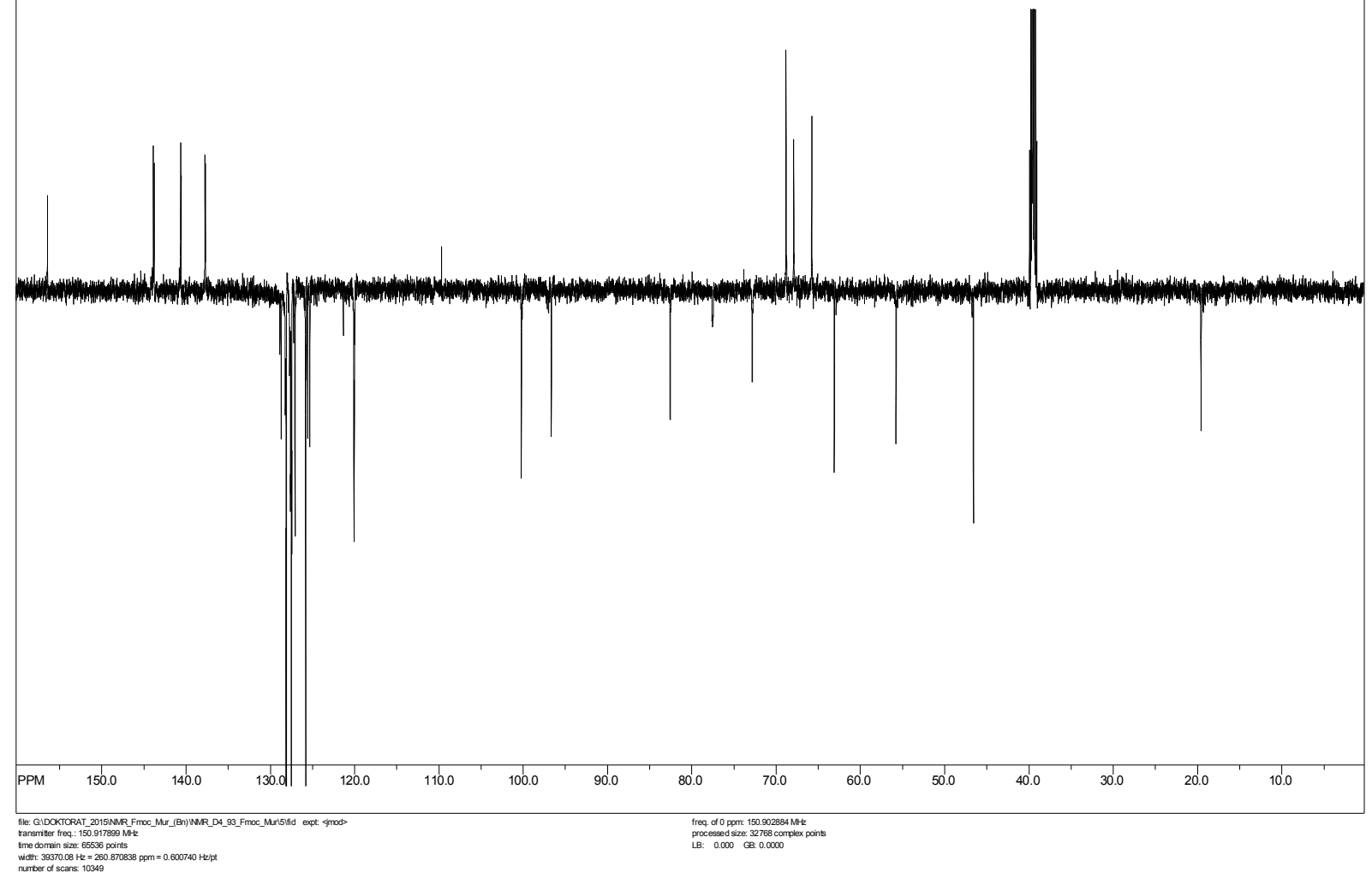

